\title{
Wastewater Management: Bibliometric Analysis of Scientific Literature
}

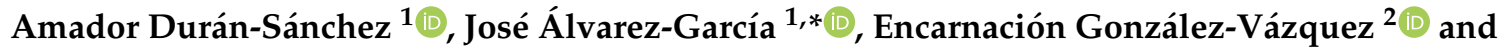 \\ María de la Cruz Del Río-Rama ${ }^{3}$ (D) \\ 1 Financial Economy and Accounting Department, Faculty of Business, Finance and Tourism, \\ University of Extremadura, 10071 Cáceres, Spain; amduransan@unex.es \\ 2 Business Management and Marketing Department, Faculty of Economics and Business, University of Vigo, \\ 36310 Vigo, Spain; egzlez@uvigo.es \\ 3 Business Management and Marketing Department, Faculty of Business Sciences and Tourism, \\ University of Vigo, 32004 Ourense, Spain; delrio@uvigo.es \\ * Correspondence: pepealvarez@unex.es; Tel.: +34-609-880-141
}

Received: 13 September 2020; Accepted: 19 October 2020; Published: 22 October 2020

\begin{abstract}
Two of the greatest challenges that threaten sustainable development are the water supply crisis together with the control of water resources pollution. The United Nations recognises that the right to safe drinking water and sanitation is an essential right, and states are called upon to intensify their efforts to provide the entire population with affordable access to safe drinking water. However, due to population growth and climate change, water resources are under great pressure, producing millions of cubic metres of wastewater. Due to the near impossibility of increasing water supply in a natural way, the importance of wastewater management as a method has grown in recent years, which, although it is not to increase the amount of this resource, but to facilitate its successive use before its final return to the sea. The objective of this article is to carry out a bibliometric analysis regarding the production and impact of the scientific research related to wastewater management indexed in the WoS and Scopus databases. The purpose is to know key aspects such as the progression of production over the years, maturity in research, coverage of the subject, identifying the most discussed topics and therefore identifying the gaps, the most relevant authors and the core of journals through which knowledge in this area is disseminated, as well as its impact through the analysis of citations. This analysis can help future researchers in this field by providing an overview of the current literature that helps them identify new research approaches to position their own work and identify the most relevant authors in this field. Likewise, a comparison is made on coverage and overlap between the two main international databases WoS and Scopus. From the analysis of the 211 articles selected through an advanced search by terms with a time limit set in 2018, it is concluded that we are facing a very incipient field of knowledge that has aroused great interest since 2010, with about half of the articles published in the period 2012-2018. Although WoS and Scopus differ in general terms in scope and coverage policies, both systems are complementary and not exclusive. In the specific area of wastewater management, Scopus is the base that provides the best coverage taking into account the number of articles published and the number of citations received.
\end{abstract}

Keywords: wastewater management; sustainability; bibliometric study; WoS; Scopus; coverage; overlap

\section{Introduction}

The United Nations General Assembly, in its Resolution 64/292, of 28 July 2010 [1], recognises that the right to safe drinking water and sanitation is an essential human right for a full enjoyment of life and of all human rights, and it calls upon states and international organizations to intensify 
their efforts to provide the entire population with affordable access to safe drinking water and sanitation. However, due to continuous population growth, especially in developing countries, and the adverse effects of climate change [2], water resources are under great pressure, producing millions of cubic metres of wastewater that pollute the environment, cause epidemics and damage ecosystems. Nowadays, 2.2 billion people lack access to safe water services and 4.2 billion lack safely managed sanitation services. Unsafe hygiene practices are widespread, making the effects on people's health worse [3].

Faced with the increasing requirements of water demand, according to a WWAP report [4], the demand for water will grow by $55 \%$ by 2050 mainly due to the growing demand for production by $400 \%$, thermal energy generation by $130 \%$ and domestic consumption by $140 \%$. It is almost impossible to increase the supply of water naturally, especially in areas with little annual rainfall. Therefore, the importance and potential of wastewater management as a method has grown in recent years, which, despite not increasing the amount of this resource, facilitates its successive use by different users before finally returning to the sea, contributing, in turn, and due to the purification prior to its reuse, to the ecological maintenance of water systems.

Wastewater recycling is emerging as an integral part of water demand management, encouraging the preservation of fresh water with high quality levels, as well as reducing pollutants in the environment and overall supply costs [5]. Recent advances in technology and changes in attitudes by both authorities and the general public towards reusing water suggest that there is still a potential improvement in wastewater management and treatment.

Therefore, the study of wastewater management has become an area that arouses great interest among researchers worldwide, generating many papers. Due to the proliferation of new research, the need for analysing the academic literature arises, in order to reach a good understanding of the state of the art, synthesizing the existing knowledge in a reproducible way, which constitutes the novelty of research, since there is none that covers this goal. Various authors point out that bibliographic reviews are a common first step to achieve this goal [6] and predict research trends $[7,8]$. Although it is true that there are some limitations in its methodology, this type of review is an adequate instrument, which provides a reasonably detailed description of research that constitutes the fundamental core within the subject analysed. Thus, the main objective of this research is to present an in-depth analysis of the published scientific literature regarding wastewater management, through a bibliometric-comparative study of the articles indexed in WoS and Scopus.

This study allows us to determine not only current trends (evolution of annual publications, productivity of both authors and journals, centres or countries, their visibility, etc.) and which of the two bases performs greater coverage, but also to identify key knowledge gaps and research priorities on this topic that serve as a starting point for researchers, by knowing the areas in which more research is needed. In the same way, and as secondary objectives, the aim is to know how much, who, what, where and how research has been conducted and to determine trends and identify areas of research in development or regression, through statistical methods, bibliometric indicators and citation analysis.

This research work is novel since there is no bibliometric study that addresses this topic: wastewater management. However, there are studies in this area of knowledge, wastewater, with similar characteristics in relation to the methodology (bibliometric analysis) that address the generation of knowledge on wastewater treatment technology [9], application of artificial intelligence to wastewater treatment [10], industrial wastewater research [11] and global research progress on pharmaceutical wastewater treatment [12].

To achieve these objectives, this document is divided into four sections. In Section 2, a review of the academic literature is carried out to establish the theoretical framework of the research. In Section 3 , both the methodology and the screening strategy used to select the references that make up the empirical basis of the study are described. In Section 4, the main results obtained in the study of the basic bibliometric indicators are detailed and discussed, as well as the analysis of overlap and 
singularity between the bases. Section 5 ends with the exposition of the conclusions and the limitations of the investigation.

\section{Theoretical Framework}

The water supply crisis and the control of water resources pollution are two of the greatest challenges that threaten the sustainable development of populations all over the world [13]. "Clean Water and Sanitation" is one of the 17 Sustainable Development Goals recommended by the United Nations, to achieve access to adequate and equitable sanitation and hygiene for all, to end with the problems of open defecation and also to improve water quality by reducing pollution [14]. Over the last century, global water use has increased six-fold. Although the current global demand for water is approximately $4600 \mathrm{~km}^{3}$ per year, it is estimated that it will increase $20-30 \%$ and reach $5500-6000 \mathrm{~km}^{3}$ per year in 2050, with the increase in domestic and industrial demand greater than that of agricultural demand [15]. However, agriculture (including irrigation, livestock and aquaculture) will remain by far the largest consumer of water, accounting for $69 \%$ of the world's annual water withdrawals. Industry (including energy production) represents 19\%, and households $12 \%$ [16].

At the same time as the resource quantities required increase, human activities cause a significant increase in the presence of pollutants, such as nutrients [17], antibiotics [18], heavy metals [19] and organic compounds (dissolved or dispersed compounds in water that come from household, agricultural and industrial waste and soil erosion) [20], in aquatic systems. In turn, this excessive discharge of nutrients, resulting from point and non-point sources, is causing great harm to ecosystems, harmful algal blooms [21], proliferation of "dead zones" [22] and a decrease in aquatic biodiversity [23]. For all these reasons, in recent years, the development of new systems for wastewater management, which are capable of providing drinking water to different users at the same rate as the population increases, have been encouraged, thus ensuring both the quantity and quality of the water available [24].

Throughout history, wastewater management has involved far-reaching technical and political challenges for both users and government leaders. The history of waste and wastewater management is both a story of ingenuity and human fragility [25]. There are several key events that defined the speed at which environmental management evolved over the centuries. Some were scientific (stream purification models), while others were socioeconomic (two World Wars) [26]. However, from the observation and study of the past, we can deduce that progress in wastewater management and sanitation was driven mainly by political coalitions that brought together industrialists, municipalities and social reformers [27].

Currently, proper management of wastewater continues to be a major challenge. In industrialized countries, the standard solution is centralized wastewater management [28] in which wastewater is collected by a sewage system of a defined area and then treated in a central sewage treatment plant [29]. Meanwhile, in most developing countries, decentralized wastewater management is an increasingly accepted option as an alternative to centralized management [30]. In this management model, wastewater is treated closer to the source, using independent modular subsystems for individual users or groups of users [29]. The use of these subsystems would provide greater flexibility and resilience, being their application the most favourable in rapidly developing regions that lack large resources and the necessary infrastructure [31], but it also has disadvantages such as the risk of a decrease in the provision of services, costs, difficult to manage in densely populated urban areas and the shift from national to local responsibility can lead to a deterioration in the quality of service. As a consequence of wastewater treatment, the discharge of effluents (discharge of water or waste used in industrial, urban or agricultural processes) is increasingly regulated at country level and even at international level, such as in the European Union, where the first common wastewater regulation was established in the 1990s [32], which must be applied and updated periodically to ensure compliance and protection of the environment and avoid social conflicts. However, some Member States do not respect its legislation [33]. 
A modern society involves many activities that produce waste and sewage. Thorough knowledge of the various wastewater sources is an essential condition prior to establishing the optimal scale, local or global, to determine where, when and how much wastewater has to be collected and the most appropriate treatment options. However, while some of these sources are well-identified and characterized, other sources are constantly emerging or are being overlooked [34]. Among all the common wastewater sources, we can consider households, large water consumers [35], large wastewater producers, hospitals [36], rain and its subsequent run-off [37], industry [38], livestock [39] and agriculture [40]. Some of the emerging sources are hydraulic fracturing (fracking) [41], fire extinguishing operations [42], spillways [43] and river or maritime transport [44].

The pollutants that are dissolved in wastewater are diverse and are concentrated in most of the existing scientific literature [34], divided into two large groups: chemical and non-chemical pollutants. The former includes nutrients, which are one of the first water pollutants known to exist [27], whose elimination processes are the focus of research [45]. The latter is pharmaceutical and personal care products, which depend to a great extent on the legislation of each country and which increases as new drugs are developed [46]. Pesticides are also an important type of wastewater pollutants. Although their use is sometimes associated with agriculture, they also appear without an apparent explanation, which reveals an unknown source [47]. Heavy metals cover a wide range of chemical products (cadmium, chromium, copper, iron, lead, mercury, selenium or zinc), and their presence in water is associated with health problems [48]. Other chemical pollutants are dyes [49], perfluorooctanoic substances [50] and radionuclides (radioactive isotopes of elements such as strontium, selenium or uranium from the cleaning of nuclear power plants) [51].

Within the second group of non-chemical pollutants, we find micro-plastics (which in many cases water treatment plants are not prepared to ensure their disposal, thus ending up discharged into the aqueous environment) [52] and nanoparticles (for example, silver, zinc oxide or silicon dioxide) [53]. Finally, pathogens represent another type of pollutants of great concern. Their detailed study is a complex task that is not the objective of this study, only to mention that they can be divided into several categories [34]: viruses [54], parasites and protozoa [55,56] and bacteria [57].

Wastewater management strategies were already implemented by ancient civilizations [27]. Today, conventional wastewater treatment consists of a combination of physical, chemical and biological processes that allow for the disposal of solids, organic matter and nutrients. We can include the following as the main wastewater treatment processes: the membrane bioreactor (MBR) [58]; the retention of pollutants through membranes by means of filtration, ultrafiltration, nanofiltration or osmosis [59]; retention by sorption (surprise) [60]; and advanced oxidation processes (AOP) [61].

\section{Methodology}

The set of articles published in scientific journals constitute a representative sample of international research activity [62]. Due to the boom that scientific production has experienced in all areas of knowledge, especially in recent decades, the need to quantify certain aspects of the documentation generated emerges to compare, measure and objectify this activity.

Bibliometrics arises to respond to this need. It is defined as the quantitative description of a set of related documents that provides an overview of a research field according to a wide variety of indicators [63]. Bibliometrics is considered an interdisciplinary science focused on the analysis of bibliographic data through statistical and mathematical tools [64].

As in other research methodologies, before starting a thorough bibliometric analysis, we must draw a mental map, where the most important steps to follow in the process of systematic bibliography search are outlined [65]. Figure 1 shows the structure followed to develop the bibliometric analysis, which is focused on wastewater management (consisting of structuring and developing the infrastructure and other systems to operate efficiently in the management of wastewater; collecting and transporting wastewater; treating wastewater; storing and transporting treated wastewater; and taking advantage of solid wastewater treatment by-products). 


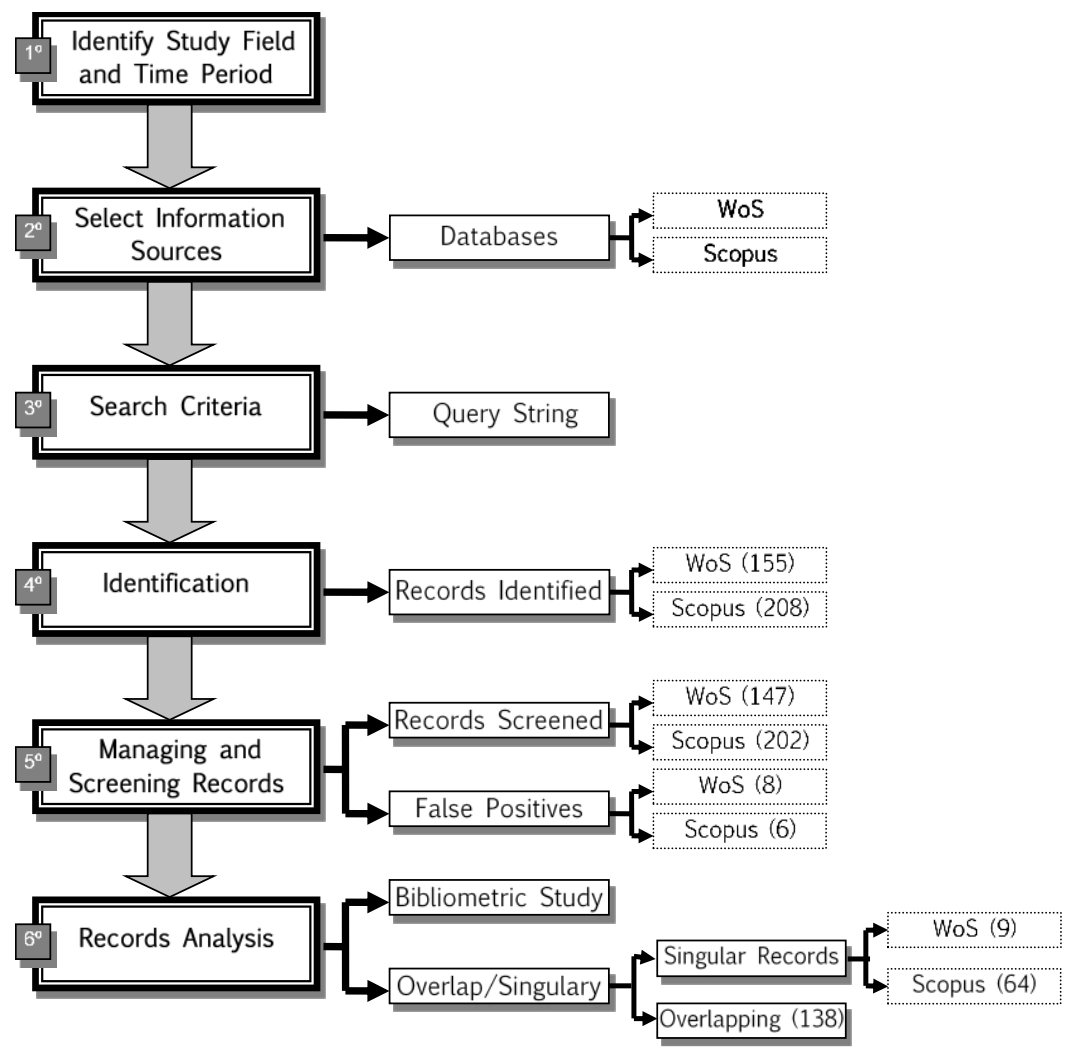

Figure 1. Basic methodological scheme followed in the bibliometric analysis. Source: Own elaboration.

Since access to scientific production in its entirety is an unattainable goal, all bibliometric analysis is limited by the availability, relevance and reliability of the information handled [66]. Thus, after identifying the field of study and determining the period of time to be analysed, the next step is to establish the appropriate database for the study.

Bibliographic databases have become an essential resource for any bibliometric study as they enable to analyse the scientific activity carried out by researchers, centres, regions and countries; to detect strengths and weaknesses; and to identify trends in research. However, the existence today of a multitude of them, both nationally and internationally, generic and specialized, makes it necessary to evaluate their greater or lesser coverage in each particular area, since the validity of the results obtained will largely depend on the suitability of the database choice [67]. In our bibliometric analysis, which is focused on the study of articles related to wastewater management, the WoS and Scopus databases are examined and compared as a primary source of information, both of which are global references that have been the subject of comparisons from their coverage perspective: articles collected, journal titles, subject and geographic areas, affiliation, languages and citation analysis [68-70].

After choosing the most appropriate databases to be used (WoS and Scopus), the next step is to establish the search criteria to be used. To be able to limit the results to the wastewater management area, we opted for document tracking through the search for terms, whose equation appears in Table 1 , which is a strategy that allows us to track journals classified within all thematic areas. Therefore, it is considered the most exhaustive [71]. 
Table 1. Essential parameters of the search strategy.

\begin{tabular}{|c|c|}
\hline Search Word & Wastewater Management \\
\hline Category & Title \\
\hline Subject area & ALL \\
\hline Document type & Journal article \\
\hline Period time & Year of publication $\leq 2018$ \\
\hline Language & English \\
\hline Query String & 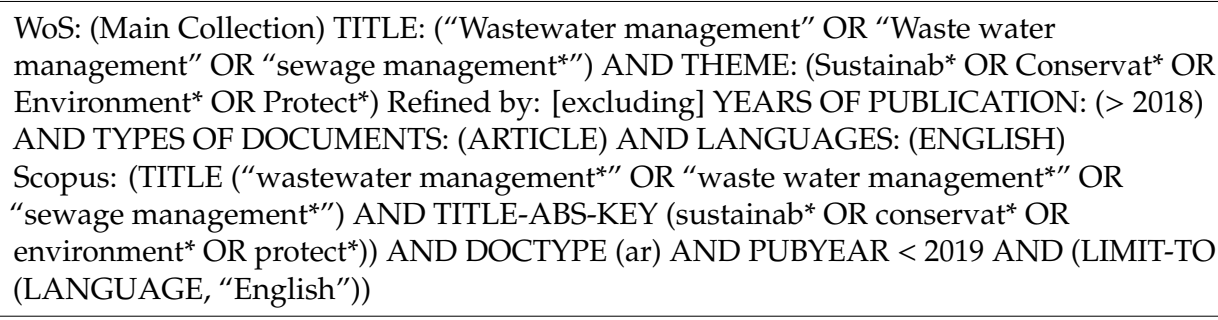 \\
\hline Search Date & February 2019 \\
\hline
\end{tabular}

Once the documents that are going to be part of the database created ad hoc for our study have been selected, the last step to follow is their classification and analysis. Many of the proposals to carry out this work [72] use the number of articles (total articles, articles per author and authors per article), the number of citations (total citations, average citations both by year and by articles, authors and institutions or countries) or the h-index, which considers both the number of articles and the number of citations they receive, that is, an author has an " $h$ " index if he/she has " $h$ " articles that have been cited at least "h" times [73].

\section{Results and Discussion}

This section shows the main results found in our bibliometric and overlap analysis of the articles found in the WoS and Scopus databases, which address the wastewater management problem.

\subsection{Production}

In Table 2, which compares the WoS and Scopus databases of the production of articles on wastewater management, selected through the search equations seen in the previous section, 2015 and 2017 stand out as the years with the highest production of articles within the period analysed, and the articles published in 2000 and 2001 as those with the highest number of total citations received. The years after 2016, despite having many articles, have not reached their maximum number of citations yet. It is interesting to note that, in the last seven years (2012-2018), published articles add up to $46.26 \%$ of the total of WoS articles and $40.59 \%$ of Scopus, which would demonstrate the interest shown in recent years for the need to manage wastewater in a sustainable way, before being returned to its natural environment. 
Table 2. Comparison of article production between WoS and Scopus.

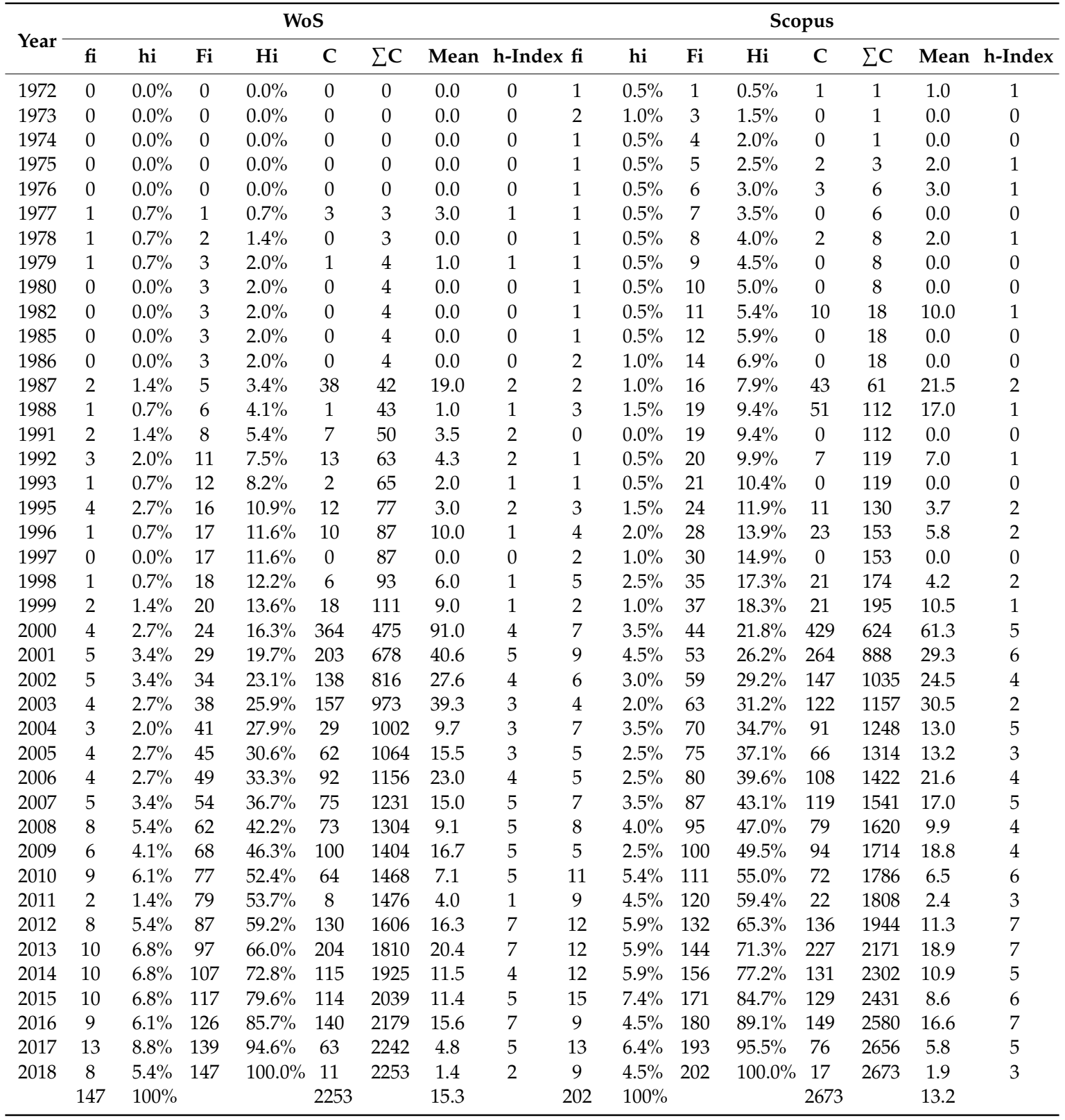

fi, frequency (number of articles published); hi, relative frequency; $\mathrm{Fi}$, accumulated absolute frequency; $\mathrm{Hi}$, accumulated relative frequency; $C$, citations received; $\Sigma C$, accumulated citations received; $h$, Hirsch's index (the index $\mathrm{h}$ measures the number of " $\mathrm{X}$ of documents" that have received " $\mathrm{X}$ citations" or more, and at the same time does not have " $X+1$ documents" with " $X+1$ citations" or more). Source: Own elaboration.

Price [74] found that the growth of scientific information was exponential and at such a rate that every 10-15 years the existing global information doubles (Price's law). Although each discipline will undergo its own evolution, all of them through the same stages: precursors (first publications); exponential growth (becomes a focus of research); and linear growth (growth slows down, review and knowledge file).

Focusing on the research, as observed in Figure 2, wastewater management is in the exponential growth phase, adjusting the accumulated production function to an exponential equation with $\mathrm{R}^{2}=0.8742$. 


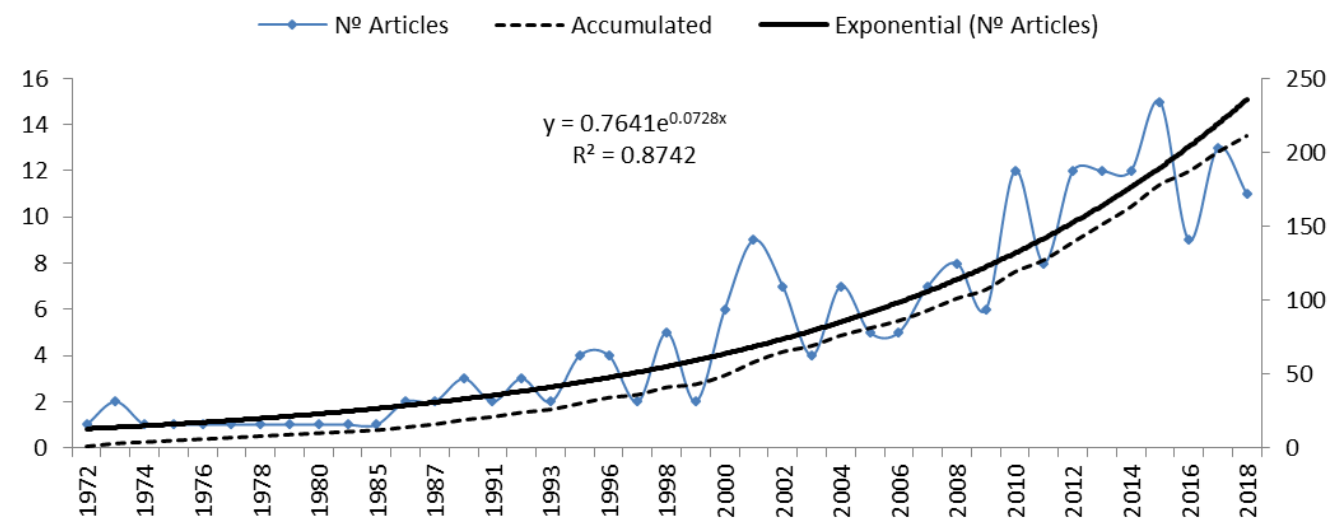

Figure 2. Growth curve of the production of articles on wastewater management. Source: Own elaboration.

When arranging the annual distribution of the number of articles included in WoS compared to Scopus, the existence of a strong correlation between both databases is confirmed. Figure 3 shows the representation of these data and their fit to a line with a correlation coefficient equal to $0.90\left(R^{2}=0.81\right)$, that is, this line explains $81 \%$ of the relationship between the number of articles published per year.

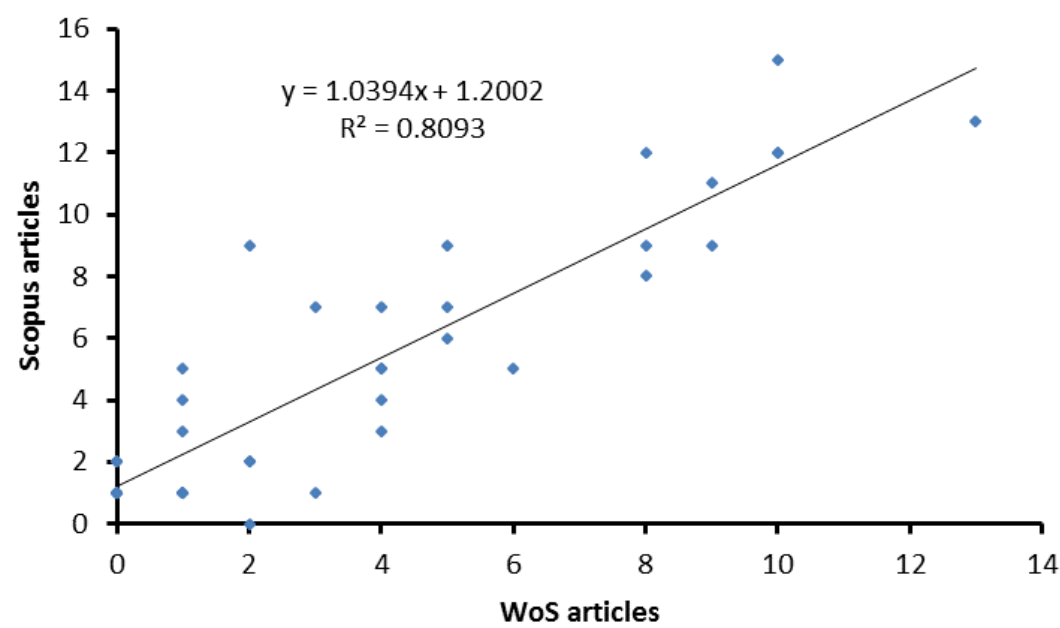

Figure 3. Correlation between the number of articles published per year in WoS and Scopus. Source: Own elaboration.

\subsection{Citations}

As shown in Table 2, the 147 documents indexed in WoS received 2253 citations and the average number of citations of the articles published in the same year was 15.3 citations/document. Regarding Scopus figures, although they are higher, they follow a similar behaviour to WoS, whose 108 articles received 1449 citations, with an average of 35.81. From the h-index perspective, both bases coincide in reaching their maximum level in the years 2012, 2013 and 2016, with an h-index of 7. At this point, it should be noted that articles do not reach their maximum citation level until 10 years after their first publication [75].

In addition, Figure 4 shows a constant growth in the number of citations that articles receive per year, a fact that constantly occurs practically during the entire period observed, reaching the maximum figure of 274 citations in WoS and 310 in Scopus in 2019. As stated regarding production, the $\mathrm{R}^{2}=0.9956$ allows affirming that there is a strong correlation between the number of citations received per year between both WoS and Scopus. 

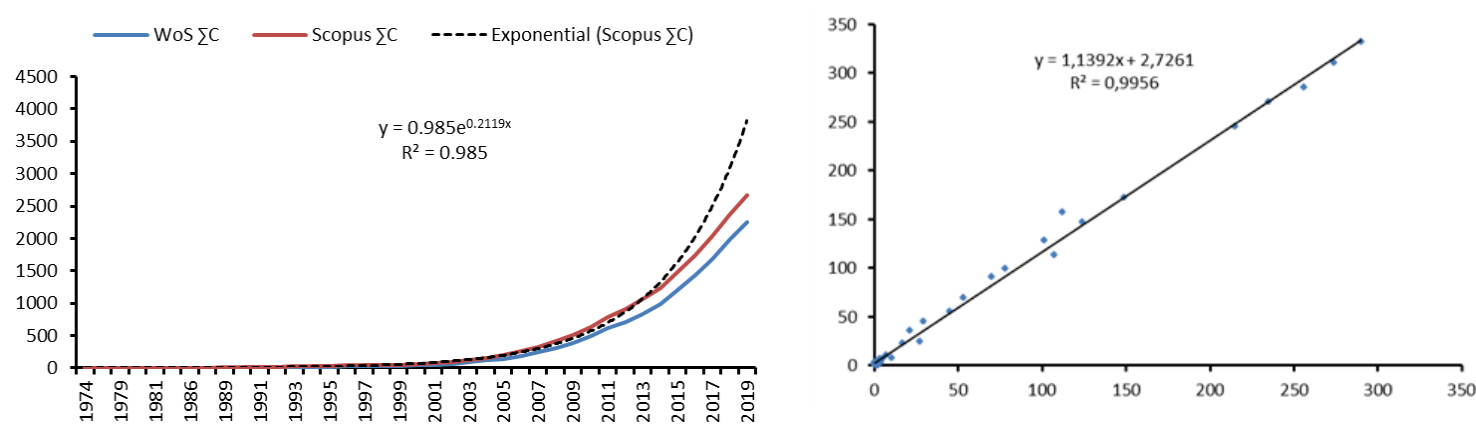

Figure 4. Growth and correlation of citations per year for articles on wastewater management. Source: Own elaboration.

If the citation analysis were performed focusing on the articles, the 147 articles in WoS received an average of 15.3 citations/article, with an h-index of 26, while, in Scopus, its 202 articles obtained an average of 13.2 citations/article, with an h-index of 28. A more detailed citation analysis shows that only $1.36 \%$ (2) of WoS articles and $1.49 \%$ (3) of Scopus articles receive more than 100 citations; $4.08 \%$ (6) and 4.46\% (9), respectively, received 50-100 citations; 38.78\% (57) and 30.69\% (62) 10-49; and 49.66\% (73) and 43.07 (87) 1-9 (Table 3). Only 6.12\% (9) of WoS articles and 20.30\% (41) of Scopus articles have not received any citations. 
Table 3. Articles most cited in WoS and Scopus: wastewater management.

\begin{tabular}{|c|c|c|c|c|c|c|c|c|c|}
\hline \multirow{2}{*}{ Author/s } & \multirow{2}{*}{ Year } & \multirow{2}{*}{ Age } & \multirow{2}{*}{ Title } & \multicolumn{4}{|c|}{ WoS } & \multicolumn{2}{|c|}{ Scopus } \\
\hline & & & & $\mathbf{R}$ & $\mathrm{C}$ & C/Age & $\mathbf{R}$ & $\mathrm{C}$ & C/Age \\
\hline $\begin{array}{l}\text { Knight, R.L. } \\
\text { Paayne, V.W.E. } \\
\text { Borer, R.E. } \\
\text { Clarke, R.A. } \\
\text { Pries, J.H. [39] }\end{array}$ & 2000 & 19 & $\begin{array}{l}\text { Constructed wetlands for livestock } \\
\text { wastewater management }\end{array}$ & 1 & 254 & 13.4 & 1 & 247 & 13.0 \\
\hline $\begin{array}{c}\text { Rahm, B.G. } \\
\text { Bates, J.T. } \\
\text { Bertola, L.R. } \\
\text { Galford, A.E. } \\
\text { Yoxtheimer, D.A. } \\
\text { Riha, S.J. [76] }\end{array}$ & 2013 & 6 & $\begin{array}{l}\text { Wastewater management and } \\
\text { Marcellus Shale gas development: } \\
\text { Trends, drivers, and planning } \\
\text { implications }\end{array}$ & 2 & 103 & 17.2 & 2 & 118 & 19.7 \\
\hline $\begin{array}{l}\text { Wilderer, P.A. } \\
\text { Schreff, D. }\end{array}$ & 2000 & 19 & $\begin{array}{l}\text { Decentralized and centralized } \\
\text { wastewater management: a } \\
\text { challenge for technology developers }\end{array}$ & 3 & 94 & 4.9 & 3 & 100 & 5.3 \\
\hline $\begin{array}{c}\text { Nandy, T. } \\
\text { Shastry, S. } \\
\text { Kaul, S.N. [28] }\end{array}$ & 2002 & 17 & $\begin{array}{l}\text { Wastewater management in a cane } \\
\text { molasses distillery involving } \\
\text { bioresource recovery }\end{array}$ & 4 & 89 & 5.2 & 4 & 94 & 5.5 \\
\hline $\begin{array}{l}\text { Parkinson, J. } \\
\text { Tayler, K. [77] }\end{array}$ & 2003 & 16 & $\begin{array}{l}\text { Decentralized wastewater } \\
\text { management in peri-urban areas in } \\
\text { low-income countries }\end{array}$ & 5 & 81 & 5.1 & 5 & 87 & 5.4 \\
\hline $\begin{array}{l}\text { Larsen, T.A. } \\
\text { Peters, I. } \\
\text { Alder, A. } \\
\text { Eggen, R. } \\
\text { Maurer, M. } \\
\text { Muncke, J. [78] }\end{array}$ & 2001 & 18 & $\begin{array}{l}\text { Re-engineering the toilet for } \\
\text { sustainable wastewater } \\
\text { management }\end{array}$ & 6 & 69 & 3.8 & - & 87 & 4.8 \\
\hline $\begin{array}{l}\text { Harrington, R. } \\
\text { Mclnnes, R. [79] }\end{array}$ & 2009 & 10 & $\begin{array}{l}\text { Integrated Constructed Wetlands } \\
\text { (ICW) for livestock wastewater } \\
\text { management }\end{array}$ & 7 & 65 & 6.5 & 7 & 68 & 6.8 \\
\hline Bakir, H.A. [31] & 2001 & 18 & $\begin{array}{l}\text { Sustainable wastewater } \\
\text { management for small communities } \\
\text { in the Middle East and North Africa }\end{array}$ & 8 & 60 & 3.3 & 9 & 60 & 3.3 \\
\hline $\begin{array}{l}\text { Kapellakis, I.E. } \\
\text { Tsagarakis, K.P. } \\
\text { Avramaki, C. } \\
\text { Angelakis, A.N. [80] }\end{array}$ & 2006 & 13 & $\begin{array}{l}\text { Olive mill wastewater management } \\
\text { in river basins: A case study in } \\
\text { Greece }\end{array}$ & 9 & 45 & 3.5 & 10 & 55 & 4.2 \\
\hline $\begin{array}{c}\text { Bajsa, O. } \\
\text { Nair, J. } \\
\text { Mathew, K. } \\
\text { Ho, G.E. [81] }\end{array}$ & 2003 & 16 & $\begin{array}{l}\text { Vermiculture as a tool for domestic } \\
\text { wastewater management }\end{array}$ & 10 & 41 & 2.6 & 11 & 53 & 3.3 \\
\hline $\begin{array}{l}\text { Burkhard, R. } \\
\text { Deletic, A. } \\
\text { Craig, A. [82] }\end{array}$ & 2000 & 19 & $\begin{array}{l}\text { Techniques for water and } \\
\text { wastewater management: A review } \\
\text { of techniques and their integration } \\
\text { in planning }\end{array}$ & - & - & - & 8 & 60 & 3.2 \\
\hline
\end{tabular}

$\mathrm{R}$, rank; $\mathrm{C}$, the total number of citations per year; $\mathrm{C} /$ Age, average citations received by years. Source: Own elaboration.

\subsection{Overlap and Singularity}

As shown above, 147 articles related to wastewater management were found in the WoS database compared to 202 articles identified in Scopus. In total, 138 of these articles are overlapping, i.e. they are present in both databases, which represent almost $94 \%$ of WoS documents and $68 \%$ of Scopus. The rest of the articles, $9(6.12 \%)$ and $64(31.68 \%)$, respectively, are single articles, i.e. they are present in only one of them (Figures 5 and 6 and Table 4 ). If the variable analysed is journals, the percentage of overlap is similar in WoS, but somewhat lower in Scopus, remaining at $68 \%$. 

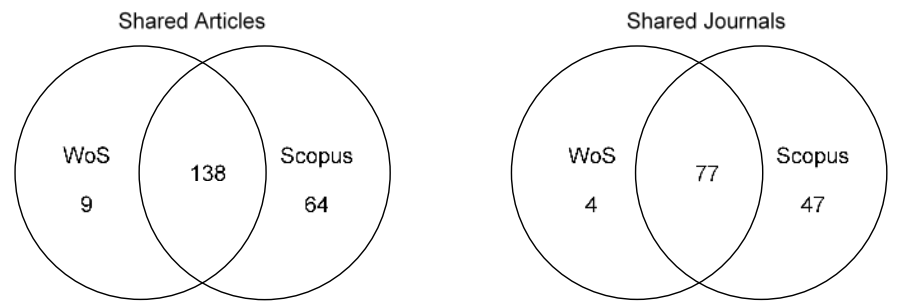

Figure 5. Overlap between WoS and Scopus around the water governance area. Source: Own elaboration.

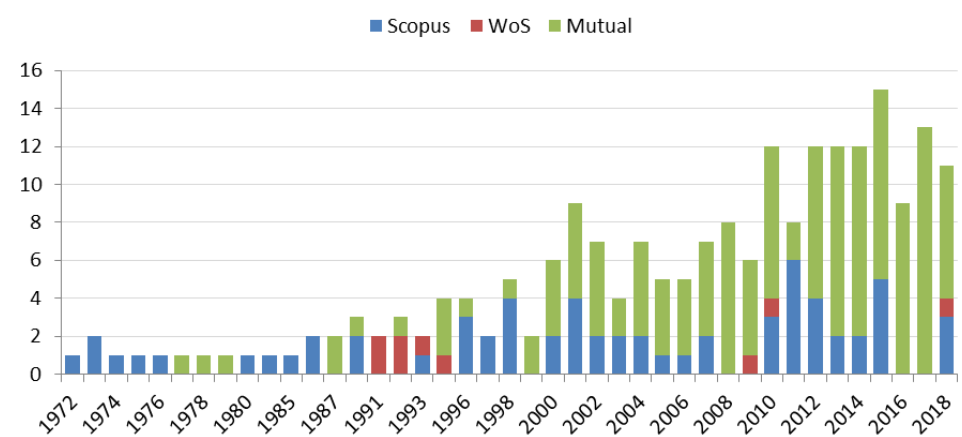

Figure 6. Evolution of article overlap between WoS and Scopus. Source: Own elaboration.

Table 4. Uniqueness of WoS and Scopus.

\begin{tabular}{ccccc}
\hline \multirow{2}{*}{ Databases } & \multicolumn{2}{c}{ Per Cent Single Documents } & \multicolumn{2}{c}{ Meyer's Index } \\
\cline { 2 - 5 } & Articles & Journals & Articles & Journals \\
\hline WoS & $6.12 \%$ & $4.94 \%$ & 0.53 & 0.52 \\
Scopus & $31.68 \%$ & $37.90 \%$ & 0.66 & 0.69 \\
\hline
\end{tabular}

Source: Own elaboration.

Figure 6 shows the distribution of the number of overlapping and single articles by years indexed in both databases.

Another way of measuring overlap between databases is through the so-called traditional overlap (TO) developed by Gluck [83].

$$
\% \mathrm{TO}=100 \times\left(\frac{\mid \text { WoS } \cap \text { Scopus } \mid}{\mid \text { WoS } \cap \text { Scopus } \mid}\right)=>\% \mathrm{TO}=100 \times \frac{138}{147+202-138}=>\% \mathrm{TO}=65.4 \%
$$

Based on the definition of the traditional overlap concept, this result would be interpreted as there being a $65.4 \%$ similarity or resemblance between articles on wastewater management when comparing WoS and Scopus, or, on the contrary, we find a disparity of $34.6 \%$

However, we use relative overlap to observe the percentage of Scopus coverage with respect to WoS and vice versa [84]:

$$
\% \text { TO WOS }=100 \times\left(\frac{\mid \text { WoS } \cap \text { Scopus } \mid}{\text { WoS }}\right)=>\% \text { TO WoS }=100 \times \frac{138}{147}=93.88 \%
$$

That is, Scopus covers $93.88 \%$ of WoS articles in the wastewater management area. The \%TO Scopus $=68.32 \%$, thus WoS covers Scopus by almost $25 \%$ less.

These differences that exist in the overlapping of articles may be due to different indexing policies, but they are mainly produced by the discrepancy in the number of journals that both databases collect.

Meyer's index [85] allowed analysing the uniqueness of WoS and Scopus. This index indicates the degree of overlap between the bases and provides the percentage of single documents. Based on the 
results obtained by its calculation (Table 4), Scopus shows greater singularity, with $31.68 \%$ of articles and $37.90 \%$ of single journals and a Meyer's index of 0.66 and 0.69 , respectively.

\subsection{Concentration}

The main objective of concentration measures or indices is to quantify the degree of inequality in the distribution or allotment of a magnitude among a certain number of "units". At this point, we analyse the Lorenz curve and the Gini concentration index as valid instruments to analyse a higher or lower concentration in the distribution of articles among the different journals in which they are published.

Lorenz curve (Figure 7): Graphic representation frequently used to capture the relative distribution of a variable (number of articles) in a given domain (journals in which they are published).
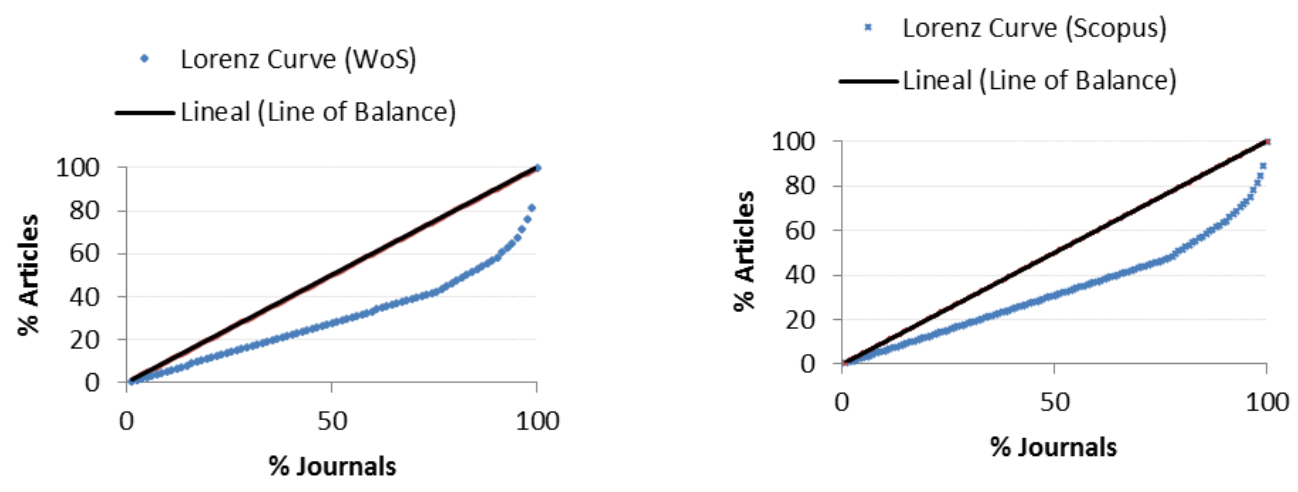

Figure 7. Lorenz curves for the distribution of articles in WoS and Scopus. Source: Own elaboration.

Gini index: Its value is between 0 and 1, with zero being maximum equality (all journals publish the same number of articles) and 1 being maximum inequality (all articles belong to a single journal). This same concept of inequality can be understood graphically through the Lorenz curve.

$$
\mathrm{I}_{\mathrm{g}}=\sum_{\mathrm{i}=1}^{\mathrm{r}-1}\left(\mathrm{p}_{\mathrm{i}}-\mathrm{q}_{\mathrm{i}}\right) / \sum_{\mathrm{i}=1}^{\mathrm{r}-1} \mathrm{p}_{\mathrm{i}}
$$

$\mathrm{q}_{\mathrm{i}}=$ Cumulative evolution of articles expressed in percentages

$p_{i}=$ Cumulative evolution of journals expressed in percentages

$$
\mathrm{I}_{\mathrm{g}}(\text { Scopus })=0.3403 ; \mathrm{I}_{\mathrm{g}}(\mathrm{WoS})=0.4012
$$

As $\operatorname{Ig}(\mathrm{WoS})>\operatorname{Ig}$ (Scopus) - although both indices are similar, in WoS, there is a higher concentration of articles in a smaller number of journals, i.e., in proportion, there is a greater inequality in the distribution, where a few journals publish a greater number of articles.

According to Bradford's law [86], there is a small number of journals (Bradford Core) that group most of the articles published around a research area. The Bradford Core is calculated based on the Minimum Zone (MBZ) (number of articles equal to half the number of journals that produce a single article) and of the ranking of journals arranged in descending order of productivity. The Bradford Core is made up of those journals whose sum of articles was equal to the MBZ $\left(\mathrm{MBZ}_{\mathrm{WoS}}=31\right.$ and $\left.\mathrm{MBZ}_{\text {Scopus }}=48\right)$. For the specific case of the bibliometric analysis on wastewater management (Table 5), this core is made up of two journals in the case of WoS and five in the case of Scopus. Water Science \& Technology stands out from the rest, collecting 27 articles in WoS and 23 in Scopus. 
Table 5. Magazines that make up the core of Bradford.

\begin{tabular}{|c|c|c|c|c|c|c|c|c|c|c|c|}
\hline \multirow{2}{*}{ WoS Journals } & \multicolumn{5}{|c|}{ WoS } & \multirow{2}{*}{ Scopus Journals } & \multicolumn{5}{|c|}{ Scopus } \\
\hline & fi & hi $\%$ & $\mathrm{C}$ & h & Q & & fi & hi $\%$ & $\mathrm{C}$ & h & Q \\
\hline Water Science \& Technology & 27 & 18.37 & 403 & 11 & Q3 & Water Science \& Technology & 23 & 11.39 & 429 & 10 & Q2 \\
\hline Desalination \& Water Treatment & 9 & 6.12 & 39 & 3 & Q3 & Desalination \& Water Treatment & 9 & 4.46 & 20 & 4 & Q2 \\
\hline J. of Environmental Management & 8 & 5.44 & 329 & 7 & Q1 & J. of Environmental Management & 8 & 3.96 & 350 & 7 & Q1 \\
\hline J. of Cleaner Production & 6 & 4.08 & 114 & 6 & Q1 & J. of Cleaner Production & 6 & 2.97 & 118 & 6 & Q1 \\
\hline J. of Environmental Health & 4 & 2.72 & 6 & 1 & Q4 & J. of Environmental Health & 6 & 2.97 & 9 & 2 & Q4 \\
\hline
\end{tabular}

Note: in bold magazines that make up the core of Bradford. R., rank; fi, frequency (number of articles published);

hi\%, relative frequency; $\mathrm{C}$, the total number of citations received by the published articles; h, Hirsch's index; $\mathrm{Q}$, quartile. Source: Own elaboration.

The comparison between the thematic areas of both databases is not possible as there is no clear correspondence between them, neither in their name nor in their content (Table 6). In both WoS and Scopus, most of the articles are included in the Environmental Science category, with 128 articles in WoS $(87.07 \%)$ and 164 in Scopus $(87.19 \%)$, being, in turn, the ones that receive the highest number of citations.

Table 6. Main Subject Areas in which the articles on wastewater management are classified.

\begin{tabular}{|c|c|c|c|c|c|c|c|c|c|c|c|}
\hline \multicolumn{6}{|c|}{ WoS } & \multicolumn{6}{|c|}{ Scopus } \\
\hline Area & fi & hi $\%$ & $\mathrm{C}$ & $\mathrm{C} / \mathrm{fi}$ & $\mathbf{h}$ & Area & fi & hi\% & $\mathrm{C}$ & $\mathrm{C} / \mathrm{fi}$ & $\mathbf{h}$ \\
\hline $\begin{array}{l}\text { Environmental } \\
\text { Sciences Ecology }\end{array}$ & 128 & 87.07 & 2098 & 16.4 & 24 & Environmental Science & 164 & 81.19 & 2530 & 15.4 & 27 \\
\hline Water Resources & 103 & 70.07 & 1372 & 13.3 & 21 & Engineering & 44 & 21.78 & 364 & 8.3 & 12 \\
\hline Engineering & 86 & 58.50 & 1343 & 15.6 & 21 & Social Science & 38 & 18.81 & 400 & 10.5 & 11 \\
\hline $\begin{array}{l}\text { Public Environmental } \\
\text { Occupational Health }\end{array}$ & 72 & 48.98 & 1301 & 18.1 & 22 & Earth and Planetary Sciences & 16 & 7.92 & 161 & 10.1 & 6 \\
\hline
\end{tabular}

\subsection{Authors}

According to the criteria proposed by Lotka [87], there are no authors considered large producers, that is, with 10 publications or more. Only $6.11 \%$ (36) of authors are intermediate producers with 2-9 authorships, while practically all of them, $553(93.89 \%)$, are known as transient with a single authorship. Consequently, a low author production leads to the productivity index being at a low 1.08. Table 7 shows the most productive authors: Larsen, T.A. with five publications, followed by Starkl, M. with four and a group consisting of four authors with three authorships each: Amin, A.T.M.N., Karrman, E., Orthon, D. and Tsagarakis, K.P.

A collaboration index of 3 together with a degree of collaboration of $80.57 \%$ shows a clear image of a high researcher cooperation level when carrying out work on wastewater management (Table 8). It should be noted that, although $80.57 \%$ of the documents have multiple authorship, $47.39 \%$ of them are written by two or three authors. Another fact to be highlighted is the very high transience index of the authors $(9.372 \%)$, which means that the vast majority of authors have only contributed one paper.

By country (Table 9), and taking into account the number of articles that both WoS and Scopus produce, the United States stands out in both databases with 15.65\% (23) of WoS articles and $17.33 \%$ (35) of Scopus articles, followed by India with 6.8\% (10) and 11.39\% (23), respectively, and Australia with $6.12 \%$ (9) and $5.94 \%$ (12). If the number of citations to establish the ranking were considered, the United States would still lead the ranking with 639 and 689 citations, respectively, followed by Canada (318 and 308), Germany (202 and 213) and Switzerland (170 and 254) 
Table 7. Authors with 3 or more publications.

\begin{tabular}{|c|c|c|c|c|c|c|c|c|c|c|c|c|c|c|c|c|}
\hline \multirow{2}{*}{ R. } & \multirow{2}{*}{ Name } & \multirow{2}{*}{ Affiliation } & \multirow{2}{*}{ Country } & \multirow{2}{*}{ Tfi } & \multicolumn{6}{|c|}{ WoS } & \multicolumn{6}{|c|}{ Scopus } \\
\hline & & & & & fi & LA & SA & $\mathrm{C}$ & $\mathrm{C} / \mathrm{fi}$ & $\mathbf{h}$ & fi & LA & SA & $\mathrm{C}$ & $\mathrm{C} / \mathrm{fi}$ & h \\
\hline 1 & Larsen, T.A. & $\begin{array}{c}\text { Swiss. Fed. Inst. } \\
\text { Aqua. } \\
\text { Sci./Technol. }\end{array}$ & Switzerland & 5 & 5 & 2 & 1 & 145 & 29 & 5 & 5 & 2 & 1 & 171 & 34.2 & 5 \\
\hline 2 & Starkl, M. & $\begin{array}{l}\text { U. of Natural } \\
\text { Resources and } \\
\text { Life Science }\end{array}$ & Austria & 4 & 4 & 3 & 0 & 35 & 8.8 & 4 & 4 & 3 & 0 & 35 & 8.75 & 4 \\
\hline 3 & $\begin{array}{l}\text { Amin, } \\
\text { A.T.M.N. }\end{array}$ & $\begin{array}{l}\text { Asian Institute of } \\
\text { Technology (AIT) }\end{array}$ & Thailand & 3 & 3 & 0 & 0 & 37 & 12 & 3 & 3 & 0 & 0 & 36 & 12 & 3 \\
\hline- & Karrman, E. & $\begin{array}{l}\text { Chalmers } \\
\text { University of } \\
\text { Technology }\end{array}$ & Sweden & 3 & 1 & 0 & 0 & 22 & 22 & 1 & 3 & 2 & 0 & 44 & 14.7 & 1 \\
\hline- & Orhon, D. & $\begin{array}{c}\text { Istanbul Technical } \\
\text { University }\end{array}$ & Turkey & 3 & 3 & 1 & 0 & 28 & 9.3 & 2 & 3 & 1 & 0 & 30 & 10 & 2 \\
\hline- & $\begin{array}{l}\text { Tsagarakis, } \\
\text { K.P. }\end{array}$ & $\begin{array}{c}\text { Democritus } \\
\text { University of } \\
\text { Thrace }\end{array}$ & Greece & 3 & 3 & 1 & 0 & 87 & 29 & 3 & 3 & 1 & 0 & 99 & 33 & 3 \\
\hline
\end{tabular}

R., rank; Tfi, frequency (number of articles published); LA, Lead Author; SA, Second Author; C, the total number of citations received by the published articles; C/fi, average citations received by the published articles; $h$, Hirsch's index. Source: Own elaboration.

Table 8. Some indicators associated with authorship.

\begin{tabular}{ccc}
\hline Index & Calculation & Results \\
\hline Transiency Index & (Number of authors with a single article & $93.72 \%$ \\
published/Total number of authors) $\times 100$ & Number of authorships/Number of articles & 3.00 \\
Degree of Collaboration & (Number of articles with multiple & authorship/Total number of articles) $\times 100$ \\
Productivity Index & Number of authorships/Number of authors & $1.08 \%$ \\
\hline & Source: Own elaboration.
\end{tabular}

Table 9. Main countries according to the affiliation of their authors.

\begin{tabular}{|c|c|c|c|c|c|c|c|c|c|c|c|}
\hline \multirow{2}{*}{$\mathbf{R}$. } & \multirow{2}{*}{ Country } & \multicolumn{4}{|c|}{ WoS } & \multirow{2}{*}{ R. } & \multirow{2}{*}{ Country } & \multicolumn{4}{|c|}{ Scopus } \\
\hline & & fi & hi $\%$ & $\mathrm{C}$ & h & & & fi & hi\% & $\mathrm{C}$ & h \\
\hline 1 & $\begin{array}{l}\text { United } \\
\text { States }\end{array}$ & 23 & 15.65 & 639 & 11 & 1 & $\begin{array}{l}\text { United } \\
\text { States }\end{array}$ & 35 & 17.33 & 689 & 11 \\
\hline 2 & India & 10 & 6.80 & 153 & 5 & 2 & India & 23 & 11.39 & 209 & 6 \\
\hline 3 & Australia & 9 & 6.12 & 66 & 4 & 3 & Australia & 12 & 5.94 & 104 & 5 \\
\hline 4 & Germany & 8 & 5.44 & 202 & 7 & 4 & England & 11 & 5.45 & 110 & 5 \\
\hline 5 & Turkey & 7 & 4.76 & 52 & 4 & 5 & Canada & 9 & 4.46 & 308 & 5 \\
\hline- & Canada & 7 & 4.76 & 318 & 5 & - & Germany & 9 & 4.46 & 213 & 7 \\
\hline- & England & 7 & 4.76 & 135 & 4 & - & Thailand & 9 & 4.46 & 68 & 6 \\
\hline- & Greece & 7 & 4.76 & 143 & 6 & - & Turkey & 9 & 4.46 & 65 & 4 \\
\hline- & Thailand & 7 & 4.76 & 65 & 6 & 9 & Greece & 8 & 3.96 & 164 & 6 \\
\hline 10 & Poland & 6 & 4.08 & 14 & 2 & 10 & Poland & 7 & 3.47 & 18 & 3 \\
\hline- & Switzerland & 6 & 4.08 & 170 & 6 & - & Switzerland & 7 & 3.47 & 254 & 7 \\
\hline
\end{tabular}

\section{Conclusions}

In this last section, the main conclusions reached in our study on the current state of research in wastewater management are shown, based on the bibliometric analysis of the scientific articles indexed in the WoS and Scopus databases. At the same time, and due to the different indexing policies 
carried out by these bases, some of the conclusions of the comparative study of overlap and singularity between both databases are also collected in order to clarify which is the most convenient to use due to its coverage of the wastewater management area.

With the use of the so-called bibliometric indicators, indexes that synthesize the scientific activity carried out in the field of research in a simple and reasoned way, it is easy to verify that, although we are dealing with an area which emerged many years ago (the first article appeared in 1972), it was not until 2010 that there was a real interest and an exponential growth in published articles related to wastewater management. In fact, more than half of the production is concentrated in the eight-year period from 2010 to 2018. Due to the fact they are currently in the exponential growth phase within the life cycle of the area, it is foreseeable that this behaviour will continue during the next few years, being, therefore, an attractive field for present and future researchers. In parallel with the growth in the number of articles, the growth in the number of citations that publications receive per year is constant and reached its highest level in 2018. Both facts, growth in production and growth in citations, would support the importance and need for this current study. Regarding the databases, the existence of a strong correlation between WoS and Scopus was observed in relation to the number of articles published annually and number of citations received, producing practically a parallel growth.

Despite the fact that there are these and other similarities between the two databases, similar to other areas [69], Scopus is the database that provides greater coverage, by collecting a greater number of documents and obtaining more citations. In addition, it has more than $31.68 \%$ of single documents and overlaps WoS articles by $93.88 \%$. In other words, the information that would be lost if we had to choose Scopus as the only documentary source would not even account for $7 \%$ of the total number of articles found.

According to the criteria proposed by Lotka [87], it was observed that there are no authors considered large producers (with 10 publications or more). Only $6.11 \%$ (36) of authors are intermediate producers, with 2-9 authorships, while practically all of them, $553(93.89 \%)$, are known as transient with a single authorship. Consequently, a low author production leads to the productivity index being at a low 1.08. The most productive authors are Larsen, T.A. with five publications, followed by Starkl, M. with four and a group consisting of four authors with three authorships each: Amin, A.T.M.N., Karrman, E., Orthon, D. and Tsagarakis, K.P. A collaboration index of 3 together with a degree of collaboration of $80 \%$ shows a clear picture of the high researcher cooperation level when carrying out work on wastewater management. Although there is multiple authorship in a high percentage of documents, almost half of them are written by two or three authors. In turn, a very high transience index of the authors indicates that the vast majority of authors have only contributed with one work. By country, and according to the number of articles that both WoS and Scopus produce, the United States stands out in both databases, followed by India and Australia. On the other hand, if we look at the number of citations as a criterion when establishing the ranking by countries, the United States still holds the first position, followed now by Canada, Germany and Switzerland.

To finish with the main results achieved in the bibliometric analysis, we must mention that there is a well-defined core of journals that collect most of the published articles on wastewater management, which is made up of two journals in the case of WoS and five in that of Scopus, with Water Science \& Technology standing out from the rest. Although it may be a simple task to compare WoS and Scopus in aspects such as production or citation, the same is not the case with regard to subject areas. Despite this fact, there are certain similarities. Both in WoS and Scopus, most of the articles are included in the environmental science category, being, in turn, the one that receives the highest number of citations. Other prominent areas are engineering, water resources and social science.

The information obtained allows us to observe that it is a very incipient area of research, in which there are practically no consolidated research groups on the subject from any of the branches of knowledge from which the subject can be approached. The articles identified address wastewater management models, environmental impact, issues related to water quality and water recycling, among others. However, this research is clearly insufficient, thus it can be said that there is a large gap 
in research on wastewater management to be addressed from the branches of knowledge of science, health sciences, social and legal sciences and engineering. This lack of information is corroborated by the World Water Resources report [88].

Since scientific research is necessary for informed decision making, as well as to support both theoretical and practical progress in this area of research, there is still a long way to go. Therefore, more research is needed to provide the knowledge necessary to improve wastewater management and to take advantage of its potential as a sustainable resource. According to the World Water Resources Report [88], "shows that improved wastewater management is as much about reducing pollution at the source, as removing contaminants from wastewater flows, reusing reclaimed water and recovering useful by-products. Together, these four actions generate social, environmental and economic benefits for all society, contributing to overall well-being and health, water and food security, and sustainable development."

Taking into account these four actions (reuse, recovery, recycling and recovery), technological innovations and the paradigm shift towards water management as a component of a circular economy [88], it is necessary to carry out research, without intending to be exhaustive, in: management models (centralized and decentralized management) in developing and developed countries, in rural or urban areas, research on optimizing water management (cost-benefit), management financing, software information systems for management, technological innovation applied to management, new business models related to the recovery of wastewater resources, use of wastewater as an alternative source of water, analysis of the impact of external factors in wastewater management (research on the impact of climate change is emerging [89], but many other external factors remain to be analysed), wastewater treatment and recovery of useful by-products from wastewater (power generation electricity, heating and cooling and recovery of salts, nitrogen and phosphorus).

Although it has been shown that bibliometric studies are tools capable of analysing the main trends in a field of study, two limitations that any study of these characteristics faces must be taken into account when interpreting the results obtained: (1) the choice of databases; and (2) the bias involved in using a specific search equation. However, the aim of this paper is not to evaluate the content quality of the selected documents, but rather a descriptive-comparative analysis, which includes an analysis of the citations received. As a possible line of future research, it would be interesting to extend the comparative study to other databases, carrying out collaborative analysis or delving into the content of documents.

Author Contributions: Conceptualization, Investigation, Methodology, Formal Analysis, Writing-Original Draft Preparation and Writing-Review \& Editing, A.D.-S., J.Á.-G., E.G.-V., and M.d.l.C.d.R.-R. All authors have read and agreed to the published version of the manuscript.

Funding: This research received no external funding.

Conflicts of Interest: The authors declare no conflict of interest.

\section{References}

1. U.N. Resolución A/RES/64/292. 2010. Available online: https://www.un.org/en/ga/search/view_doc.asp? symbol=A/RES/64/292 (accessed on 5 July 2020).

2. Gosling, S.N.; Arnell, N.W. A global assessment of the impact of climate change on water scarcity. Clim. Change 2016, 134, 371-385. [CrossRef]

3. WHO (World Health Organization). Progress on Household Drinking Water, Sanitation and Hygiene 2000-2017: Special Focus on Inequalities; World Health Organization: Geneva, Switzerland, 2019; Available online: https://www.who.int/water_sanitation_health/publications/jmp-report-2019/en/ (accessed on 5 July 2020).

4. WWAP (United Nations World Water Assessment Programme). The United NationsWorld Water Development Report 2016: Water and Jobs; UNESCO: Paris, France, 2016.

5. Al-Jayyousi, O.R. Greywater reuse: Towards sustainable water management. Desalination 2003, 156, 181-192. [CrossRef] 
6. Tranfield, D.; Denyer, D.; Smart, P. Towards a methodology for developing evidence-informed management knowledge by means of systematic review. Br. J. Manag. 2006, 14, 207-222. [CrossRef]

7. Fahimnia, B.; Sarkis, J.; Davarzani, H. Green supply chain management: A review and bibliometric analysis. Int. J. Prod. Econ. 2015, 162, 101-114. [CrossRef]

8. Bornmann, L.; Mutz, R. Growth rates of modern science: A bibliometric analysis based on the number of publications and cited references. J. Assoc. Inf. Sci. Technol. 2015, 66, 2215-2222. [CrossRef]

9. Patyal, V.; Jaspal, D.; Khare, K. Wastewater treatment technologies: A bibliometric analysis. Sci. Technol. Lib. 2020, 1-12. [CrossRef]

10. Zhao, L.; Dai, T.; Qiao, Z.; Sun, P.; Hao, J.; Yang, Y. Application of artificial intelligence to wastewater treatment: A bibliometric analysis and systematic review of technology, economy, management, and wastewater reuse. Process Saf. Environ. Prot. 2020, 133, 169-182. [CrossRef]

11. Zheng, T.; Wang, J.; Wang, Q.; Nie, C.; Smale, N.; Shi, Z.; Wang, X. A bibliometric analysis of industrial wastewater research: Current trends and future prospects. Scientometrics 2015, 105, 863-882. [CrossRef]

12. Qian, F.; He, M.; Song, Y.; Tysklind, M.; Wu, J. A bibliometric analysis of global research progress on pharmaceutical wastewater treatment during 1994-2013. Environ. Earth Sci. 2015, 73, 4995-5005. [CrossRef]

13. Engin, K.; Tran, M.; Connor, R.; Uhlenbrook, S. The United Nations World Water Development Report 2018: Nature-Based Solutions for Water; Facts and Figures; UNESCO: Paris, France, 2018.

14. United Nations Development Programme (UNDP) Take Action for the Sustainable Development Goals. United Nations Development Programme: New York, NY, USA; Available online: www.un.org/ sustainabledevelopment/sustainable-development-goals/ (accessed on 10 July 2020).

15. Burek, P.; Satoh, Y.; Fischer, G.; Kahil, M.T.; Scherzer, A.; Tramberend, S.; Nava, L.S.; Wada, Y.; Eisner, S.; Flörke, M. Water Futures and Solution: Fast Track Initiative (Final Report); IIASA Working Paper: Vienna, Austria, 2016.

16. AQUASTAT. Food and Agriculture Organization of the United Nations (FAO). Available online: www.fao. org/nr/water/aquastat/water_use/index.stm (accessed on 24 May 2020).

17. Tong, Y.; Qiao, Z.; Wang, X.; Liu, X.; Chen, G.; Zhang, W.; Dong, X.; Yan, Z.; Han, W.; Wang, R. Human activities altered water N: P ratios in the populated regions of China. Chemosphere 2018, 210, 1070-1081. [CrossRef]

18. Hao, R.; Zhao, R.; Qiu, S.; Wang, L.; Song, H. Antibiotics crisis in China. Science 2015, 348, $1100-1101$. [CrossRef] [PubMed]

19. Nriagu, J.O. A history of global metal pollution. Science 1996, 272, 223. [CrossRef]

20. Wen, Y.; Schoups, G.; Van De Giesen, N. Organic pollution of rivers: Combined threats of urbanization, livestock farming and global climate change. Sci. Rep. 2017, 7, 43289. [CrossRef] [PubMed]

21. Wang, M.; Xu, X.; Wu, Z.; Zhang, X.; Sun, P.; Wen, Y.; Wang, Z.; Lu, X.; Zang, W.; Wang, X.; et al. Seasonal pattern of nutrient limitation in a Eutrophic lake and quantitative analysis of the impacts from internal nutrient cycling. Environ. Sci. Technol. 2019, 53, 13675-13686. [CrossRef] [PubMed]

22. Diaz, R.J.; Rosenberg, R. Spreading dead zones and consequences for marine ecosystems. Science 2008, 321, 926-929. [CrossRef] [PubMed]

23. Vörösmarty, C.J.; McIntyre, P.B.; Gessner, M.O.; Dudgeon, D.; Prusevich, A.; Green, P.; Glidden, S.; Bunn, S.E.; Sullivan, C.A.; Liermann, R.; et al. Global threats to human water security and river biodiversity. Nature 2010, 467, 555-561. [CrossRef]

24. Robinson, T.; McMullan, G.; Marchant, R.; Nigam, P. Remediation of dyes in textile effluent: A critical review on current treatment technologies with a proposed alternative. Bioresour. Technol. 2001, 77, 247-255. [CrossRef]

25. HDR (Human Development Report). Beyond Scarcity: Power, Poverty and the Global Water Crisis; United Nations Development Programme: New York, NY, USA, 2006.

26. Shifrin, N.S. Pollution management in the twentieth century. J. Environ. Eng. 2005, 131, 676-691. [CrossRef]

27. Lofrano, G.; Brown, J. Wastewater management through the ages: A history of mankind. Sci. Total Environ. 2010, 408, 5254-5264. [CrossRef]

28. Wilderer, P.A.; Schreff, D. Decentralized and centralized wastewater management: A challenge for technology developers. Water Sci. Technol. 2001, 41, 1-8. [CrossRef]

29. Libralato, G.; Ghirardini, A.V.; Avezzù, F. To centralise or to decentralise: An overview of the most recent trends in wastewater treatment management. J. Environ. Manag. 2010, 94, 61-68. [CrossRef] [PubMed] 
30. Massoud, M.A.; Tarhini, A.; Nasr, J.A. Decentralized approaches to wastewater treatment and management: Applicability in developing countries. J. Environ. Manag. 2009, 90, 652-659. [CrossRef] [PubMed]

31. Bakir, H.A. Sustainable wastewater management for small communities in the Middle East and North Africa. J. Environ. Manag. 2001, 61, 319-328. [CrossRef]

32. EEC. Council Directive 91/271/EEC Concerning Urban Wastewater Treatment; European Union: Brussels, Belgium, 1991.

33. Voulvoulis, N.; Arpon, K.D.; Giakoumis, T. The EU Water Framework Directive: From great expectations to problems with implementation. Sci. Total Environ. 2017, 575, 358-366. [CrossRef]

34. Villarín, M.C.; Merel, S. Paradigm shifts and current challenges in wastewater management. J. Hazard. Mater. 2020, 390, 122-139. [CrossRef]

35. Gleick, P.H. Basic water requirements for human activities: Meeting basic needs. Water Int. 1996, $21,83-92$. [CrossRef]

36. Mompelat, S.; Le Bot, B.; Thomas, O. Occurrence and fate of pharmaceutical products and by-products, from resource to drinking water. Environ. Int. 2009, 35, 803-814. [CrossRef] [PubMed]

37. Burkhardt, M.; Zuleeg, S.; Vonbank, R.; Schmid, P.; Hean, S.; Lamani, X.; Bester, K.; Boller, M. Leaching of additives from construction materials to urban storm water runoff. Water Sci. Technol. 2011, 63, 1974-1982. [CrossRef]

38. Ashrafi, O.; Yerushalmi, L.; Haghighat, F. Wastewater treatment in the pulp-and-paper industry: A review of treatment processes and the associated greenhouse gas emission. J. Environ. Manag. 2015, 158, 146-157. [CrossRef]

39. Knight, R.L.; Payne, V.W., Jr.; Borer, R.E.; Clarke, R.A., Jr.; Pries, J.H. Constructed wetlands for livestock wastewater management. Ecol. Eng. 2000, 15, 41-55. [CrossRef]

40. Raschid-Sally, L.; Carr, R.; Buechler, S. Managing wastewater agriculture to improve livelihoods and environmental quality in poor countries. J. Int. Com. Irrig. Drain. 2005, 54, S11-S22. [CrossRef]

41. Lutz, B.D.; Lewis, A.N.; Doyle, M.W. Generation, transport, and disposal of wastewater associated with Marcellus Shale gas development. Water Resour. Res. 2013, 49, 647-656. [CrossRef]

42. Merel, S.; Benzing, S.; Gleiser, C.; Di Napoli-Davis, G.; Zwiener, C. Occurrence and overlooked sources of the biocide carbendazim in wastewater and surface water. Environ. Pollut. 2018, 239, 512-521. [CrossRef]

43. Clarke, B.O.; Anumol, T.; Barlaz, M.; Snyder, S.A. Investigating landfill leachate as a source of trace organic pollutants. Chemosphere 2015, 127, 269-275. [CrossRef] [PubMed]

44. Magnusson, K.; Jalkanen, J.P.; Johansson, L.; Smailys, V.; Telemo, P.; Winnes, H. Risk assessment of bilge water discharges in two Baltic shipping lanes. Mar. Pollut. Bull. 2018, 126, 575-584. [CrossRef] [PubMed]

45. Kelly, P.T.; He, Z. Nutrients removal and recovery in bioelectrochemical systems: A review. Bioresour. Technol. 2014, 153, 351-360. [CrossRef] [PubMed]

46. Petrie, B.; Barden, R.; Kasprzyk-Hordern, B. A review on emerging contaminants in wastewaters and the environment: Current knowledge, understudied areas and recommendations for future monitoring. Water Res. 2015, 72, 3-27. [CrossRef] [PubMed]

47. Becouze-Lareure, C.; Dembélé, A.; Coquery, M.; Cren-Olivé, C.; Barillon, B.; Bertrand-Krajewski, J.L. Source characterisation and loads of metals and pesticides in urban wet weather discharges. Urban Water J. 2016, 13, 600-617. [CrossRef]

48. Westerhoff, P.; Lee, S.; Yang, Y.; Gordon, G.W.; Hristovski, K.; Halden, R.U.; Herckes, P. Characterization, recovery opportunities, and valuation of metals in municipal sludges from US wastewater treatment plants nationwide. Environ. Sci. Technol. 2015, 49, 9479-9488. [CrossRef]

49. Raman, C.D.; Kanmani, S. Textile dye degradation using nano zero valent iron: A review. J. Environ. Manag. 2016, 177, 341-355. [CrossRef]

50. Zareitalabad, P.; Siemens, J.; Hamer, M.; Amelung, W. Perfluorooctanoic acid (PFOA) and perfluorooctanesulfonic acid (PFOS) in surface waters, sediments, soils and wastewater-A review on concentrations and distribution coefficients. Chemosphere 2013, 91, 725-732. [CrossRef] [PubMed]

51. Park, Y.; Lee, Y.C.; Shin, W.S.; Choi, S.J. Removal of cobalt, strontium and cesium from radioactive laundry wastewater by ammonium molybdophosphate-polyacrylonitrile (AMP-PAN). Chem. Eng. J. 2010, 162, 685-695. [CrossRef]

52. Carr, S.A.; Liu, J.; Tesoro, A.G. Transport and fate of microplastic particles in wastewater treatment plants. Water Res. 2016, 91, 174-182. [CrossRef] 
53. Zhang, Y.; Leu, Y.R.; Aitken, R.J.; Riediker, M. Inventory of engineered nanoparticle-containing consumer products available in the Singapore retail market and likelihood of release into the aquatic environment. Int. J. Environ. Res. Public Health 2015, 12, 8717-8743. [CrossRef] [PubMed]

54. Eftim, S.E.; Hong, T.; Soller, J.; Boehm, A.; Warren, I.; Ichida, A.; Nappier, S.P. Occurrence of norovirus in raw sewage-A systematic literature review and meta-analysis. Water Res. 2017, 111, 366-374. [CrossRef]

55. Ajonina, C.; Buzie, C.; Rubiandini, R.H.; Otterpohl, R. Microbial pathogens in wastewater treatment plants (WWTP) in Hamburg. J. Toxicol. Environ. Health 2015, 78, 381-387. [CrossRef]

56. Daniels, M.E.; Smith, W.A.; Jenkins, M.W. Estimating Cryptosporidium and Giardia disease burdens for children drinking untreated groundwater in a rural population in India. PLoS Negl. Trop. Dis. 2018, 12, e0006231. [CrossRef]

57. Cai, L.; Zhang, T. Detecting human bacterial pathogens in wastewater treatment plants by a high-throughput shotgun sequencing technique. Environ. Sci. Technol. 2013, 47, 5433-5441. [CrossRef]

58. Krzeminski, P.; Leverette, L.; Malamis, S.; Katsou, E. Membrane bioreactors-A review on recent developments in energy reduction, fouling control, novel configurations, LCA and market prospects. J. Membr. Sci. 2017, 527, 207-227. [CrossRef]

59. Fane, A.G.; Wang, R.; Hu, M.X. Synthetic membranes for water purification: Status and future. Angew. Chem. Int. Ed. 2015, 54, 3368-3386. [CrossRef]

60. Hai Nguyen, T.; You, S.J.; Hosseini-Bandegharaei, A.; Chao, H.P. Mistakes and inconsistencies regarding adsorption of contaminants from aqueous solutions: A critical review. Water Res. 2017, 120, 88-116.

61. Asghar, A.; Raman, A.A.A.; Daud, W.M.A.W. Advanced oxidation processes for in-situ production of hydrogen peroxide/hydroxyl radical for textile wastewater treatment: A review. J. Clean. Prod. 2015, 87, 826-838. [CrossRef]

62. Benavides-Velasco, C.A.; Guzmán-Parra, V.; Quintana-García, C. Evolución de la literatura sobre empresa familiar como disciplina científica. Cuad. Econ. Dir. Empresa 2011, 14, 78-90. [CrossRef]

63. Nicholas, D.; Ritchie, M. Literature and Bibliometrics; Clive Bingley: London, UK, 1978.

64. Broadus, R. Toward a definition of "bibliometrics". Scientometrics 1987, 12, 373-379. [CrossRef]

65. Rowley, J.; Slack, F. Conducting a literature review. Manag. Res. News 2004, 27, 31-39. [CrossRef]

66. Rueda, G.; Gerdsri, P.; Kocaoglu, D.F. Bibliometrics and social network analysis of the nanotechnology field. In Proceedings of the Portland International Conference on Management of Engineering \& Technology (PICMET), Portland, OR, USA, 27-31 July 2007; pp. 2905-2911.

67. Norris, M.; Oppenheim, C. Comparing alternatives to the Web of Science for coverage of the social sciences' literature. J. Infometrics 2007, 1, 161-169. [CrossRef]

68. Álvarez-García, J.; Durán-Sánchez, A.; del Río-Rama, M.; García-Vélez, D. Active ageing: Mapping of scientific coverage. Int. J. Environ. Res. Public Health 2018, 15, 2727. [CrossRef]

69. Durán-Sánchez, A.; Álvarez-García, J.; Río-Rama, D.; De la Cruz, M. Sustainable water resources management: A bibliometric overview. Water 2018, 10, 1191. [CrossRef]

70. Meho, L.I.; Rogers, Y. Citation counting, citation ranking, and h-index of human-computer interaction researchers: A comparison of Scopus and Web of Science. J. Am. Soc. Inf. Sci. Technol. 2008, 59, 1711-1726. [CrossRef]

71. Corral, J.A.; Canoves, G. La investigación turística publicada en revistas turísticas y no turísticas: Análisis bibliométrico de la producción de las universidades catalanas. Cuad. Tur. 2013, 31, 55-81.

72. Cancino, C.A.; Merigo, J.M.; Torres, J.P.; Díaz, D. A bibliometric analysis of venture capital research. J. Econ. Financ. Adm. Sci. 2018, 23, 182-195. [CrossRef]

73. Hirsch, J.E. An index to quantify and individual's scientific research output. Proc. Natl. Acad. Sci. USA 2005, 102, 16569-16572. [CrossRef]

74. Price, D.J.S. The exponential curve of science. Discovery 1956, 17, 240-243.

75. Merigó, J.M.; Mas-Tur, A.; Roig-Tierno, N.; Ribeiro-Soriano, D. A bibliometric overview of the Journal of Business Research between 1973 and 2014. J. Bus. Res. 2015, 68, 2645-2653. [CrossRef]

76. Rahm, B.G.; Bates, J.T.; Bertoia, L.R.; Galford, A.E.; Yoxtheimer, D.A.; Riha, S.J. Wastewater management and Marcellus Shale gas development: Trends, drivers, and planning implications. J. Environ. Manag. 2013, 120, 105-113. [CrossRef]

77. Parkinson, J.; Tayler, K. Decentralized wastewater management in peri-urban areas in low-income countries. Environ. Urban. 2013, 15, 75-90. [CrossRef] 
78. Larsen, T.A.; Peters, I.; Alder, A.; Eggen, R.; Maurer, M.; Muncke, J. Re-engineering the toilet for sustainable wastewater management. Environ. Sci. Technol. 2001, 35, 192A-197A. [CrossRef]

79. Harrington, R.; McInnes, R. Integrated Constructed Wetlands (ICW) for livestock wastewater management. Bioresour.Technol. 2009, 100, 5498-5505. [CrossRef]

80. Kapellakis, I.E.; Tsagarakis, K.P.; Avramaki, C.; Angelakis, A.N. Olive mill wastewater management in river basins: A case study in Greece. Agric. Water Manag. 2006, 82, 354-370. [CrossRef]

81. Bajsa, O.; Nair, J.; Mathew, K.; Ho, G.E. Vermiculture as a tool for domestic wastewater management. Water Sci. Technol. 2004, 48, 125-132. [CrossRef]

82. Burkhard, R.; Deletic, A.; Craig, A. Techniques for water and wastewater management: A review of techniques and their integration in planning. Urban Water J. 2000, 2, 197-221. [CrossRef]

83. Gluck, M. A review of journal coverage overlap with an extension to the definition of overlap. J. Am. Soc. Inform. Sci. 1990, 41, 43-60. [CrossRef]

84. Bearman, T.C.; Kunberger, W.A. A Study of Coverage Overlap among Fourteen Major Science and Technology Abstracting and Indexing Services; National Federation of Abstracting and Indexing Services: Philadelphia, PA, USA, 1977.

85. Meyer, D.E.; Mehlman, D.W.; Reeves, E.S.; Origoni, R.B.; Evans, D.; Sellers, D.W. Comparison study of overlap among 21 scientific databases in searching pesticide information. Online Rev. 1983, 7, 33-43. [CrossRef]

86. Bradford, S.C. Sources of information on specific subjects. Engineering 1934, 137, 85-86.

87. Lotka, A.J. The frequency distribution of scientific productivity. J. Wash. Acad. Sci. 1926, 16, 317-323.

88. WWAP (United Nations World Water Assessment Programme). The United Nations World Water Development Report 2017. Wastewater: The Untapped Resource; UNESCO: Paris, France, 2017.

89. GWP (Global Water Partnership). Impacts of Climate on Wastewater Management. Discussion Brief No. 5. Global Water Partnership. GWP: Stockholm. 2014. Available online: www.gwp.org/Global/GWP-C\%20Files/ TOPIC $\% 205 \% 20-20 I m p a c t s \% 20$ of\%20Climate\%20n\%20Wastewater\%20Management.pdf (accessed on 5 July 2020).

Publisher's Note: MDPI stays neutral with regard to jurisdictional claims in published maps and institutional affiliations.

(C) 2020 by the authors. Licensee MDPI, Basel, Switzerland. This article is an open access article distributed under the terms and conditions of the Creative Commons Attribution (CC BY) license (http://creativecommons.org/licenses/by/4.0/). 